\title{
THE GROWTH OF POLLEN TUBES IN INCOMPATIBLE POLLINATIONS OF JAPANESE PEARS*
}

\author{
Y. ASAMI AND FujIKo Hayami \\ College of Agriculture, Tokyo Imperial University
}

The senior ${ }^{(2)(8)}$ author reported before that in the self-incompatible pollinations of the Japanese pear Chojuro the pollen tubes traced down in the stylar canal to the base with the same growth rate as that in cross-compatible pollinations, but when they were at or near the open entrance to the locule in ovary their progress was decidedly arrested and no tubes could be found in the locule. The same behaviour of pollen tubes was observed by $\operatorname{Terami}^{(6)}$ in self-incompatibility in Chojuro, and he observed further that in cross-incompatibility the pollen tubes travelled down slowly but they reached the base of style 5 days after pollination. Ushikoshi and Tokuyasu ${ }^{(7)}$ reported, however, that in cross-incompatibility in the Japanese pears the pollen tubes advanced only to a distance shorter than a half of style length, their progress being inhibited early, though they reported for Nijisseki that the pollen tubes proceeded to the base of style without delay in self-incompatibility.

As two different types of pollen-tube behaviour in incompatibility were thus reported with the Japanese pears, the authors have repeated again the investigations in 1932 and 1933.

\section{Materials and Methods}

In 1932, with the self-incompatible varieties Chojuro, Nijisseki, and Waseaka the relative rate of growth of pollen tubes down the styles of selfed and crossed flowers was determined. The material for this study was secured from a pear orchard at Inadanoborito near Tokyo. In 1933 the growth behaviour of pollen tubes in cross-incompatibility was compared with that in cross-compatibility. For this investigation the pear trees cultivated in the orchard of the Kanagawa Agri-

* This paper was presented before the horticultural section at the fifth annual meeting of the Nippon Nogaku Kwai, held at Tokyo on April 8, 1934. 
cultural Experiment Station at Ninomiya were used, and the following compatibleand incompatible-pollinations were made;

$\begin{array}{ll}\text { incompatible mating } & \text { compatible mating } \\ \text { Ichiharawase } \times \text { Meigetsu } & \text { Ichiharawase } \times \text { Hakataao } \\ \text { Taihaku } \times \text { Waseaka } & \text { Taihaku } \times \text { Nijisseki }\end{array}$

In addition to this experiment an attempt was made to observe the effect of a high temperature on the growth of pollen tubes in selfed and crossed styles. The branches with flower blossoms were cutted from the tree of Chojuro grown in an orchard at Inadanobonito, put into a bottle which contained water, and placed in a greenhouse of about $70^{\circ} \mathrm{F}$. Self- and cross-pollinations were made on the flowers of these branches.

The styles were collected at intervals, killed in Flemming's strong solution or Carnoy's fluid or Bouin's solution, embedded in paraftin, and sectioned for microscopical study. For staining cotton blue in lactic acid was used. As a water solution of resorcin blue had stained very distinctly the pollen tubes in the styles of plum flowers giving far better result than a stain with cotton blue, this stain was tried in the present study, but the poller tubes of the Japanese pears were not clearly stained with resorcin blue. In a private communication Dr. Tufts of the University of California stated that Dr. Condit attempted to use this stain for pollen tubes in fig material and could not use it at all.

\section{Results}

\section{GROWTH OF POLLEN TUBES IN SELFED AND CROSSED STYLES}

The results obtained in determing the relative rate of growth of pollen tubes in the selfed and the crossed styles, together with the result reported for Chojuro in the previous paper, ${ }^{(3)}$ are shown in table I and table II.

TABLE I- AVERAGE DISTANCE TRAVERSED BY LONGEST POLLEN TUBE IN SELFED AND CROSSED STYLES OF CHOJURO.

Experiment in 1926, trees cultivated in orchard of College of Agriculture at Komaba.

\begin{tabular}{|c|c|c|c|c|}
\hline $\begin{array}{c}\text { Time intervals in hour after } \\
\text { pollination }\end{array}$ & 6 & 17 & 24 & 48 \\
\hline Chojuro $\times$ Chojuro & $\begin{array}{c}\mathrm{mm} . \\
1.91(8)\end{array}$ & $\begin{array}{l}\mathrm{mm} . \\
1.70(6)\end{array}$ & $\begin{array}{l}\mathrm{mm} . \\
3.78(7)\end{array}$ & $\begin{array}{l}\mathrm{mm} . \\
7.50(9)\end{array}$ \\
\hline Chojuro $\times$ Imamuraaki & $2.12(6)$ & $1.73(7)$ & $4.00(0)$ & $6.59(6)$ \\
\hline
\end{tabular}

* parenthesized figure indicates number of styles averaged. 
TABLE II- AVERAGE DISTANCE TRAVERSED BY LONGEST POLLEN TUBE IN SELFED AND CROSSED STYLES.

Experiment in 1932 , trees cultivated in orchard at Inadanoborito.

\begin{tabular}{|c|c|c|c|c|}
\hline $\begin{array}{c}\text { Time intervals in hour after } \\
\text { pollination }\end{array}$ & 6 & 18 & 24 & 48 \\
\hline Chojuro $\times$ Chojuro & $1.964(7)^{*}$ & $1.288(6)$ & $\operatorname{mm}$ & $\begin{array}{l}\min \\
6.770(7)\end{array}$ \\
\hline Chojuro $\times$ Nijisseki & $1.589(8)$ & $1.931(8)$ & & $7.087(8)$ \\
\hline Nijisseki $\times$ Nijisseki & $1771(8)$ & $1958(8)$ & $3.491(8)$ & $6.670(8)$ \\
\hline Nijisseki $\times$ Waseaka & $2.030(8)$ & $1.958(6)$ & $3.573(8)$ & $7.443(8)$ \\
\hline Waseaka $\times$ Waseaka & $1.176(4)$ & $2.574(6)$ & $3.484(7)$ & $6.250(1)$ \\
\hline Waseaka $\times$ Nijisseki & $1.317(2)$ & $2.828(8)$ & $4.876(5)$ & $6.250(3)$ \\
\hline
\end{tabular}

* parenthesized figure indicates number of styles averaged.

The result obtained with Chojuro in 1926 shows, as before reported, that the growth rate of pollen tubes in the selfed was not slower than that in the crossed styles. In the determinations carried out in 1932, in Chojuro as well as Nijisseki and Waseaka the growths of pollen tubes were very slightly slower in the selfed than in the crossed styles. The difference in the length of pollen tubes between the selfed and the crossed styles collected 48 hours after pollination was less than $1 \mathrm{~mm}$., and the pollen tubes had also traversed two thirds or more than two thirds of the entire distance in the selfed styles 2 days after pollination. This relative rate of growth of pollen tubes in the selfed and the crossed styles determined in the present study agrees pretty well with that observed in Chojuro by Terami( ${ }^{(6)}$ and in Nijisseki by Ushikoshi and Tokuyasu. ${ }^{(7)}$

In cases of Chojuro and Nijisseki in our study the length of pollen tubes in the styles collected 18 hours after pollination was not longer than that in the styles taken 6 hours after pollination in the selfed as well as the crossed pistils. As mentioned in the previous report, this would be due to the fact that all the styles at 18 hours were pollinated in the evening and collected early on the following moming so that the pollen tubes had grown during the cold night. To make this point clear and also to see whether the relative rate of growth of pollen tubes in the selfed and the crossed styles is infuenced by a high temperature the determination was carried out with the flowers on the branches placed in a greenhouse of about $70^{\circ} \mathrm{F}$. The obtained results are shown in table III. 
TABLE III-AVERAGE DISTANCE TRAVERSED BY LONGEST POLLEN TUBE IN SELEED AND CROSSED STYLES OF FLOWERS OF CHOJURO PLACED IN A GREENHOUSE.

Experim nnt in 1933 , branches cutted from tree grown in orchard at Inadanoborito.

\begin{tabular}{|c|c|c|c|}
\hline $\begin{array}{c}\text { Time intervals in hour after } \\
\text { pollination }\end{array}$ & 18 & 24 & 48 \\
\hline Chojuro $\times$ Chojuro & $\begin{array}{l}\mathrm{nm} . \\
4.038(10)^{*}\end{array}$ & $\begin{array}{l}\mathrm{mm} . \\
6.052(10)\end{array}$ & $\begin{array}{ll}\mathrm{mm} . \\
7.126 \quad(6)\end{array}$ \\
\hline Chojuro $\times$ Nijisselki & $4.484 \quad(4)$ & $7.001(11)$ & $8.280(19)$ \\
\hline
\end{tabular}

* parenthesized figures indicate number of styles averaged.

In the styles collected 17 or 18 hours after pollination, the lengths of pollen tubes shown in table III are more than twice as long as those shown in table I and table II indicating that the pollen tubes continued the progress with the same rate in the night in a greenhouse while their growth became slow in the night in open air owing to the lowered temperature. In the study carried ont by Terami(6) the pollen tubes proceeded in the styles pollinated on the morning and collected on the morning of the following day farther than in those pollinated on the morning and collected in the evening of the same day. Whether or not the growth rate of pollen tubes declines in the night depends upon the temperature in the night, and the case may be, therefore, occurred in which the temperature goes not so down in the night as the growth of pollen tubes is influenced. As shown in table II, in the case of Waseaka in the present study the pollen tubes in the styles collected 18 hours after pollination travelled farther than those in the styles collected at 6 hours.

The relative rate of growth of pollen tubes in the selfed and the crossed styles in a greenhouse was the same with that in open air, and the pollen tubes in the selfed styles traversed a distance of about $6 \mathrm{~mm}$. in the first 24 hours and after that their growth rate was remarkably depressed and they made only a short progress about $1 \mathrm{~mm}$. long in the next 24 hours. The same restit was observed by Terami in his experiment carried out in a greenhouse.

In all cases in our investigations no pollen tubes were found in the ovary in the selfed pistils while in the crossed ovaries the pollen tubes appeared in the locule in 3 days, and there was no case in which the incompatible reaction between the pollen tube and the style in self pollination was complete in the upper portion of the style. 


\section{GROWTH OF POLLEN TUBES IN INCOMPATIBLE AND COMPATIBLE CROSSES}

It is a well known fact with the Japanese pears that the pollination between Ichiharawase and Meigetsu and that between Waseaka and Taihaku show the' definite incompatibility. The results obtained in determing the relative rate of pollen tube growth in compatible and incompatible crosses are shown in table IV.

TABLE IV-AVERAGE DISTANCE TRAVERSED BY LONGEST POLLEN TUBE IN COMPATIBLE AND INCOMPATIBLE CROSSES.

Experiment in 1932, trees cultivaled in orchard of Kanagawa Agricultural Experiment Stalion at Ninomiya.

\begin{tabular}{|c|c|c|c|c|c|}
\hline $\begin{array}{c}\text { Time intervals after } \\
\text { pollination }\end{array}$ & 6 hours & 1 day & 2 days & 3 days & 7 days \\
\hline $\begin{array}{l}\text { Ichiharawase } \times \text { Meigetsu } \\
\text { (incompatible cross) }\end{array}$ & $\begin{array}{l}\mathrm{mm} . \\
0.519(10)^{*}\end{array}$ & $\begin{array}{l}\mathrm{mm} . \\
1711(15)\end{array}$ & $\begin{array}{l}\text { mm. } \\
4.431 \text { (8) }\end{array}$ & $\begin{array}{l}\mathrm{mm} \\
4.09+(6)\end{array}$ & $\begin{array}{l}\mathrm{mm} . \\
5.610 \quad(6)\end{array}$ \\
\hline $\begin{array}{l}\text { Whiharawase } \times \text { Hakataao } \\
\text { (compatible cross) }\end{array}$ & $0.716(7)$ & $2.469(19)$ & $5.795(11)$ & $5.848(5)$ & \\
\hline $\begin{array}{l}\text { Taihaku } \times \text { Waseaka } \\
\text { (incompatible cross) }\end{array}$ & $1.258(10)$ & $3.570(8)$ & $5.100(9)$ & $5.171(6)$ & $6.71 \vec{a} \quad(9)$ \\
\hline $\begin{array}{l}\text { Taihaku } \times \text { Nijisseki } \\
\text { (compatible cross) }\end{array}$ & $1.586(6)$ & $7.164(7)$ & $9.223(11)$ & $8.687(10)$ & \\
\hline
\end{tabular}

* parenthesized figures indicate number of styles averaged.

In both cases of Ichiharawase and Taihaku the progress of pollen tubes in the' styles was slower in the incompatible than in the compatible crosses; and the arrest of pollen-tube growth occurred at the higher point in the style in the case of incompatible cross than in the case of self-pollination mentioned before. However, the difference between the rate of growth of pollen tubes in the compatible and the incompatible crosses was not so remarkable as that observed by Ushikoshi and Tokuyasu. (7) They reported that in the styles collected 8 or 9 days after pollination the length of pollen tubes was $4.752 \mathrm{~mm}$. in Ichiharawase pollinated with Meigetsu, and only $2.516 \mathrm{~mm}$. in Taihaku pollinated by Waseaka. In our cases, 7 days after pollination the pollen tubes had traversed the distance of $5.610 \mathrm{~mm}$. in the styles of Ichiharawase pollinated by Meigetsu and the distance of $6.715 \mathrm{~mm}$. in the styles of 'Taihaku pollinater by' Waseaka, and in each case the distance traversed by pollen tubes was longer than a half of the length of style which was on average 
$7.81 \mathrm{~mm}$. and $9.74 \mathrm{~mm}$. long in Ichiharawase and Taihaku respectively. In the case of Ichiharawase $\times$ Meigetsu observed by Terami $^{(6)}$ the pollen tubes travelled down in the style farther than in the same cross in our study, and they nearly reached the base of style in 5 days. In the styles of Ichiharawase pollinated by Meigetsu the distance traversed by the pollen tubes is the longest in the case observed by Terami, the shortest in the case reported by Ushikoshi and Tokuyasu, and of medium length between these in our case, although the differences in three cases are small.

In the case of Ichiharawase, the pollen tubes were seen in the locule of the ovary collected 3 days after pollination and the egg cell began to develop into embryo in the material fixed at 7 days in the compatible crosses, while no tubes could be found in the ovary collected 7 days after pollination in the incompatible crosses. In the ovary of Taibaku collected 7 days after pollination the fertilization of egg cell was finished in the compatible crosses but no tubes were seen in the incompatible crosses.

\section{SWOLLEN ENDS OF POLLEN TUBES}

In his studies with Petunia Yasuda ${ }^{(8)(10)(15)}$ observed that the pollen tubes formed irregular swelling at their tips in self-incompatibility. Ushikoshi and Tokuyasu $^{(i)}$ also noticed in their study with the Japanese pears that the ends of pollen tubes were swollen, though not very remarkably, in cross-incompatibility. Terami ${ }^{(6)}$ observed frequently the swollen ends of pollen tubes in the self as well as cross incompatible pollinations in the Japanese pears but scarcely in the compatible pollinations. He also mentioned that there were no swollen ends of pollen tubes to be found in the styles collected up to the 12th hour from pollination, but in the incompatible pollination, both self and cross, pretty many tubes swollen at their tips were seen here and there in the conducting tissue of the styles collected at the 24th hour, and the number of those abnormal tubes seemed to be the greatest in the styles collected 3 days after pollination.

In our present study the pollen tubes which formed a swollen end were observed in the compatible as well as incompatible pollinations. A comparison was made between compatible and incompatible pollinations on this behaviour of pollen tubes. The results obtained are shown in table $\mathrm{V}$. 
TABLE V-APPEARANCE OF POLLEN TUBE SWOLLEN AT TIP IN COMPATIBLE AND INCOMPATIBLE POLLINATION.

\begin{tabular}{|c|c|c|c|c|c|c|c|}
\hline \multicolumn{2}{|c|}{ Time intervals after pollination } & $\begin{array}{c}6 \\
\text { hours }\end{array}$ & $\begin{array}{c}18 \\
\text { hours }\end{array}$ & day & $\stackrel{2}{\text { days }}$ & $\begin{array}{c}3 \\
\text { days }\end{array}$ & $\begin{array}{c}7 \\
\text { days }\end{array}$ \\
\hline $\begin{array}{l}\text { Ichiharawase } \times \mathrm{Ha} \text { - } \\
\text { kataio } \\
\text { (compatible cross) }\end{array}$ & $\begin{array}{l}\text { No. of styles ex- } \\
\text { anined } \\
\text { No. of pollen tubes } \\
\text { swollen at end } \\
\text { Averaged no. of } \\
\text { pollen tubes swollen } \\
\text { at end per style }\end{array}$ & $\begin{array}{l}7 \\
0\end{array}$ & & \begin{tabular}{c|}
19 \\
6
\end{tabular} & $\begin{array}{l}11 \\
10\end{array}$ & $\begin{array}{c}5 \\
2 \\
0.40\end{array}$ & \\
\hline $\begin{array}{l}\text { Ichiharawase } \times \text { Mei } \\
\text { getșu } \\
\text { (incompatible cross) }\end{array}$ & $\begin{array}{l}\text { No. of styles ex- } \\
\text { amined } \\
\text { No. of pollen tubes } \\
\text { swollen at end } \\
\text { Averaged no. of } \\
\text { pollen tubes swollen } \\
\text { at end per style }\end{array}$ & 10 & & $\begin{array}{l}15 \\
4\end{array}$ & $\begin{array}{l}8 \\
8\end{array}$ & $\begin{array}{l}6 \\
8\end{array}$ & $\begin{array}{r}6 \\
14\end{array}$ \\
\hline $\begin{array}{l}\text { Taihaku } \times \text { Nijisseki } \\
\text { (compatible cross) }\end{array}$ & $\begin{array}{l}\text { No of styles ex- } \\
\text { amind } \\
\text { No. of pollen tubes } \\
\text { swollen at end } \\
\text { Averaged no. of } \\
\text { pollen tubes swollen } \\
\text { at end per style }\end{array}$ & 6 & & $\begin{array}{l}7 \\
2\end{array}$ & $\begin{array}{l}12 \\
2\end{array}$ & $\begin{array}{c}10 \\
8 \\
0.80\end{array}$ & \\
\hline $\begin{array}{l}\text { Taihaku } \times \text { Waseaka } \\
\text { (incompatible cross) }\end{array}$ & $\begin{array}{l}\text { No. of styles ex- } \\
\text { amined } \\
\text { No. of pollen tubes } \\
\text { swollen at end } \\
\text { Averaged no. of } \\
\text { pollen tubes swollen } \\
\text { at end per style }\end{array}$ & $\begin{array}{c}10 \\
1 \\
0.10\end{array}$ & & $\begin{array}{l}8 \\
7\end{array}$ & $\begin{array}{l}9 \\
7\end{array}$ & $\begin{array}{c}6 \\
13 \\
2.17\end{array}$ & $\begin{array}{c}9 \\
25 \\
\\
2.78\end{array}$ \\
\hline Chojuro $\times$ Nijisseki & $\begin{array}{l}\text { No. of styles ex- } \\
\text { amined } \\
\text { No, of pollen tubes } \\
\text { swollen at end } \\
\text { Averaged no. of } \\
\text { pollen tubes swollen } \\
\text { at end per style }\end{array}$ & v & 0 & $\begin{array}{l}11 \\
2\end{array}$ & $\begin{array}{l}12 \\
3\end{array}$ & & \\
\hline
\end{tabular}




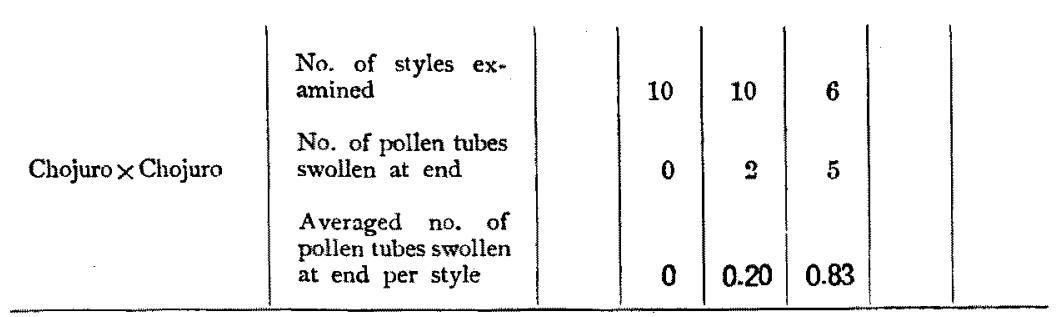

From table V, though the way of comparison was not very accurate, yet it may be seen that the pollen tubes which formed a swollen end appeared more frequently in the incompatible pollinations than in the compatible pollinations, and that, as Terami observed, they were not found in the styles collected early after pollination in both compatible and incompatible pollinations, and as the styles were collected later, they appeared therein more frequently in the incompatible pollinations.

In his study with apples Cooper(4) reported that the condition that the end of the pollen tubes become bulbous, although encountered in crossed as well as selfed flowers, was more frequently in the latter. On the other hand the opposite case is also reported. Anderson and $\operatorname{Sax}^{(1)}$ mentioned in their report for Tradescantia that on the whole there seemed to be an association between pointed ends and incompatible matings and between swollen ends and compatible matings, although apparent exceptions were noted. They said also that the whole matter, like many others connected with those experiments, was difficult of determination because of the extreme variability which seemed characterize pollen tube behaviour.

\section{Discussion}

Many different types of the behaviour of pollen tube in incompatibility are known. Between two extreme cases, one in which the pollen grains cannot germinate on stigma and the other in which the pollen tubes proceed directly into locule without delay and yet no seeds are formed, there are various cases reported. For example; some of the pollen grains germinate but the pollen tubes can hardly penetrate the stigmatic tissue; the pollen tubes penetrate the stigmatic tissue and travel down in the stylar canal but they progress slowly and only advance to a short distance; or the pollen tubes trace down in style to the base without delay but their progress is decidedly arrested near the open entrance to locule in ovary so that they cannot force their way into the locule. Out of these behaviours of pollen tubes in incompatibility the type that the growth of pollen tubes in the style is slow and arrested when the pollen tubes have traversed the distance more or less shorter than a half of the style length is reported most commonly with 
various plants. In their study with various forms of Hemerocallis Stout and Chandler ${ }^{(9)}$ observed three distinct types of pollen-tube behaviour in self-incompatibility, namely (1) the reactions of incompatibility may be complete in the upper part of the styles, (2) they are expressed at the entrance to the ovary, and (3) they are expressed within the ovary.

As to the growth behaviour of the pollen tube in self-incompatibility in the Japanese pears the result obtaind in the present study almost agrees with the condition reported by the senior, author for Chojuro, the phenomena observed by Terami(6) in the; same variety, and the result reported by Ushikoshi and Tokuyasu(7) for Nijisseki. In regard to the behaviour of the pollen tube growth in cross-incompatibility. in the Japanese pears the result obtained by the present authors, that by Terami, and that by Ushikoshi and Tokuyasu differ more or less from each other. In all these three cases the growth of pollen tubes in cross-incompatibility is slower than that in cross-compatibility, but the pollen tubes reached the base of style in 5 days in the case observed by Terami, they ceased elongation after they had traversed a distance shorter than. a half of style length in the case observed by Ushikoshi and Tokuyasu, and in the present case the pollen tubes made the elongation shorter than that in the former but longer than that in the latter. It is seen, therefore, that the behaviour of the pollen-tube growth in cross-incompatibility is not always the same, even in the same varieties, and can be different according to circumstances.

The cases are reported by various investigators in , which self-incompatibility is influenced more or less by the internal as well as external conditions of plants such as the vigors of vegetative growth, temperature, the degree of ripening of pistils, or the time of pollination in blooming season.

In a series of studies with Petunia violacea Yasuda ${ }^{(8)(10)(1)(19)(13)(14)}$ obtained. the results which indicated that the inhibition of pollen-tube growth in incompatible pollinations should be due to the toxic action of some special substances, and that these special substances should be secreted in the plancenta in ovary and go up to the styles. To explain various types of pollen-tube behaviour in incompatibility Yasuda ${ }^{(16)}$ offers the following interpretation; if the special substances produced in the ovary go up and reach the stigma before it is pollinated, they will tend to inhibit the germination of pollens, if on the other hand, they should arrive but to the style without reaching the stigma the tube growth would be inbibited at some points in the style, though the pollen would germinate on the stigma, and again if the substances stay at the ovary, the pollen tubes will grow without delay, showing 
the inhibiting phenomenon only in the ovary. With Petunia he ${ }^{(9)}$ obtained further the results which seemed to indicate that the production of the speical substances became scanty as the plant growth declined, and also it became less at the end of the blooming season.

\section{Summary}

(1) The relative rate of growth of pollen tubes in the style of selfed and crossed flowers in the Japanese pears, Chojuro, Nijisseki, and Waseaka was determined.

(2) The pollen tubes travelled down nearly to the base of style in self pollination, though their. progress was very slightly slower than that in cross pollination, but then their growth was decidedly arrested so that they could not force their way. into the ovary.

(3) In a greenhouse of about $70^{\circ} \mathrm{F}$. the pollen tubes progressed down in the style nearly twice as fast as those in open air in the first 24 hours, but after that their growth rate was decidedly depressed and no tubes penetrated into the ovary in self pollination.

(4) The behaviour of growth of pollen tubes in the incompatible crosses, Ichiharawase $\times$ Meigetsu, and Taihaku $\times$ Waseaka, was examined.

(5) The progress of pollen tubes in the style was slower in incompatible than in compatible crosses and the retardation of pollen-tube growth occurred more remarkably in the case of cross-incompatibility than in that of self-incompatibility, yet the pollen tubes had traversed more than two thirds of the entire distance in the styles collected 7 days after pollination in cross-incompatibility.

(6) The pollen tubes which formed a swollen end were seen in both compatible and incompatible pollinations, but they appeared more frequently in the styles in incompatible pollinations, and they were not found in the styles collected early after pollination in compatible as well as in incompatible pollinations, and as the style was collected later, they appeared therein more frequently in incompatible pollinations.

\section{Acknowledgments}

The writers wish to express their cordial thanks to Mr. T. Nishimune, formerly student in the College of Agriculture, Tokyo Imperial University and Mr. M. Kawaguchi of the Kanagawa Agricultural Experiment Station for their help afforded during this study, to Prof. Dr. Warren P. Tufts of the University of California and Prof. Dr. Ora Smith of the New York State College of Agriculture at Comell University for direction in methods of staining with resorcin blue, and to Prof. Dr. A. Kikuchi of the Kyoto Imperial University for lending the unpublişhed report. 


\section{Literature Cite 1}

(1) Anderson, E., and Sax, K. A cytological analysis of self-sterility in Trades. cantia. Bot. Gaz. XCV: 609-621. 1934.

(2) Asami. Y. Preliminary report on the self sterility of Japanese pear, Chojuro. Proc. Imp. Acad. $2: 139-141$. 1926.

(3) - On the self-sterility of the Japanese pear. Proc. Amer. Soc. Hort. Sci. 23 (1926) : 122-127. 1927.

(4) Cooper, J. R. The behaviour of pollen tubes in self and cross pollination. Proc. Amer. Soc. Hort. Sci. 25 (1928) : 138-140. 1929.

(5) Stout, A. B., and Chandler, C. Pollen-tube behaviour in Hemerocallis. Bull. Torr. Bot. Club, $60: 397-416.1933$.

(6) Terami, H. Studies on the pollen-tube behaviour with reference to self- and crosssterility in Japanese pears. (Unpublished).

(7) Ushikoshi, M. and Tokuyasu, K. Studies on pollination and fertilization in pears (in Japanese). Journ. Okitsu Hort. Soc. 25:135-152, 1930.

(8) Yasuda, S. Physiological researches on the fertility in Petunia violacea. VI. Growth of the pollen tubes in the style. Bot. Mag. (Tokyo), XLIII : 156-167. 1929.

(9) Physiological tesearches on the fertility of Petunia violacea. VII. On the cause of the so-called "end-season fertility". Bot. Mag. (Tokyo), XLIV : 392-403. 1930 .

(10) Physiological researches on the fertility in Petunia violacea. VIII. On the self-fertilizing ability of flowers in buds of the self-incompatible plants. Bot. Mag. (Tokyo), XLIV : 678-687, 1930.

(11) Physiological researches on the fertility in Petunia violacea. IX. Some new experiments on the nature of the special substances which inhibit self-fertilization existing in the pistil. Bot. Mag. (Tokyo), XLV : 301-313. 1931.

(12) On the special substance that inhibits self-fertilization. Bot. Mag. (Tokyo), XLVI : 225-231. 1932.

(13) Physiological researches on the fertility in Petunia violacea. $\mathrm{X}$. On the relation between the self-incompatibility and the tissue juice of the ovary. Bot. Mag. (Tokyo), XLVI : 510-517. 1932.

(14) An experiment to graft the style upon the ovary in Petunia violacea. Proc. Imp. Acad. Jap. $7: 72-75.1932$. Physiological researches on the fertility in Petunia violacea. XI. On the effect of temperature upon self-fertilization. Bot. Mag. (Tokyo), XLVI: 679.689. 1933.

(16) Studies pertaining to the self-incompatibility in some plants of Solanaceae. III. Physiological aspect of self-incompatibility in Petunia violacea. Ann. Rept. Saito Ho-on Kai, $9: 87-96.1933$. 